09 November 2015

11:56

Unfiled Notes Page 1 


\title{
The Internet, social networking Web sites and political participation research: Assumptions and contradictory evidence by Isidoropaolo Casteltrione
}

\begin{abstract}
Over the last decade there has been a proliferation of academic studies addressing the relationship between the Internet and politics, with an increasing number of publications focusing on the impact of such a medium on political participation. Within this specific sub-field research has produced contrasting evidence and generated an intense academic debate. Some scholars stressed the positive impact of the Internet on political participation (i.e., optimists), while others minimised its mobilising power, emphasising its tendency to reinforce existing participatory trends (i.e., normalisers) or highlighting its limited or even negative influence on political participation (i.e., pessimists). Similar findings also emerged in relation to social networking Web sites (SNSs), digital platforms that have been the subject of much research in recent years. This paper discusses how two assumptions characterising many studies focusing on the Internet, SNSs and political participation have contributed to the contradictory findings produced by optimists, pessimists and normalisers. The first assumption is the consideration of political participation as an activity aimed exclusively at affecting governments' actions, either directly or indirectly. This conceptualisation has arguably prevented scholars from grasping the multidimensional nature of political participation and from assessing how the influence of the Internet on this phenomenon can vary according to the different types of political activity. The second assumption is the perception of the Internet as a homogeneous platform and an over-generalised notion of Internet usage. This, in turn, has led researchers to concentrate on the online/off-line distinction and to overlook the impact of different digital tools and various usage practices. This paper argues for a shift in the ways political participation, Internet and SNSs usage are conceptualised and operationalised in academia. It suggests moving away from the polarised debate between optimists, pessimists and normalisers, and adopting a more differential approach through which examining the effects of digital technologies on political participation.
\end{abstract}

\section{Contents}

Introduction: Defining political participation

The debate between Internet optimists, pessimists and normalisers

Two assumptions in Internet and political participation research

Conclusion: The need for a differential approach

\section{Introduction: Defining political participation}

Over the last decade there has been a proliferation of academic studies addressing the relationship between the Internet and politics (Chadwick and Howard, 2009; Holtz-Bacha, 2004; Wang, 2007). Several streams of research have emerged covering a diverse array of issues including: the credibility of online political information; media ownership; commercialisation of cyberspace; online political campaigning; and citizens' political activism and participation (Tedesco, 2004). These developments in scholarship are linked to several current trends in societies such as: the progressive integration of the Internet into the lives of many individuals, social and political organisations (Baym, 2010; Chadwick, 2006; Chadwick and Howard, 2009; Papacharissi, 2011; van Dijck, 2013); the growing detachment of citizens from the political process (Dalton, 2004; Hay, 2007; Norris, 2011; Pharr and Putnam, 2000); and the changing social, psychological, technological and economic conditions (Bennett and Iyengar, 2008).

Among recent studies assessing the impact of the Internet on the realm of politics an increasing number of publications have focused on how this medium can affect citizens' political engagement 
and participation (Anduiza, et al., 2009). Investigations falling within this strand of research seem to all attribute a positive connotation to political participation. The idea that political participation is beneficial to both citizens and democratic institutions has been supported by several influential political scientists, such as Barber (1984), Evans (2001) and Fischer (2003). In line with Barber's (1984) notion of strong democracy, Evans (2001) argued that political institutions can be considered democratic only when citizens participate in the resolution of the issues affecting their lives. Along the same lines Fischer (2003) regarded citizens' participation as "the cornerstone of the democratic political process" [1] and stressed how citizens have both the right and the obligation to participate in the public decision-making process. This stance, however, is not universally recognised. For instance, as stressed by Norris [2], the realist school led by Schumpeter (1952) contended that, as long as there are fair and free elections held at regular intervals, limited public involvement was sufficient to guarantee stable and accountable government.

Nonetheless, the purpose of this paper is not to embark in an exploration of the value of political participation in democratic systems, but rather to shed light on the capability of digital technologies in supporting and promoting citizens' political participation. In order to do so the development of a clear definition of political participation is required. One of the most influential and utilised theorisations of this phenomenon is the one developed by Verba, et al. (1995), which has been adopted in many studies focusing on the impact of the Internet on political participation (e.g., Calenda and Meijer, 2009; Dimitrova, et al., 2014; Dutta-Bergman and Chung, 2005). Verba, et al. (1995) described political participation as the "activity that has the intent or effect of influencing government actions - either directly by affecting the making or implementation of public policy or indirectly by influencing the selection of people who make those policies" [3] . According to them, the ultimate purpose of political participation is mobilisation, namely influencing governments' actions, either directly (e.g., contacting public officials) or indirectly by influencing citizens. However, by focusing only on mobilisation-related activities, such a conceptualisation appears too narrow in that it excludes activities like following political events in the news or discussing politics among friends. These activities have been described by Christy (1987) as communication activities and have been the focus of numerous Internet and political participation studies (e.g., Brundidge and Rice, 2009; Morris and Morris, 2013). Communication activities are intrinsically different from the ones considered by Verba, et al. (1995) as they do not aim to influence governments but rather reflect individuals' interest and psychological involvement in politics.

Another element to consider in Verba, et al.'s (1995) theorisation is the orientation of political participation. In their account, political participation aims to affect governments' actions and, consequently, is a government-oriented activity. However, in the last couple of decades citizens' participatory repertoire has been subject to a restructuration and expansion due to changes in the ways citizens perceive politics and relate to political institutions, and to the rise and diffusion of new channels of participation like the Internet. In this sense, Norris (2002) spoke of a democratic phoenix and argued that the disengagement from traditional forms of political participation has led to the emergence of new and unconventional participatory practices. Along the same lines, considering Bennett's (1998) notion of lifestyle politics which refers to the tendency of citizens "to organise social and political meaning around their lifestyle values and the personal narratives that express them" [4], Papacharissi (2011) called for a reconsideration of the praxis of citizenship. Accordingly, in his study on Facebook groups and activism, Marichal (2013) suggested that political participation on social networking Web sites (SNSs) should be intended "less as intentional efforts to promote social and political change and more as a discursive performance designed to express a political identity".

Considering the rise of new and more individualised forms of participation, and the fact that political activities can be driven by different purposes (i.e., mobilisation vs communication), a more modern and up-to-date definition of political participation is developed in this paper. Political participation is intended here as "a set of activities influencing or aiming to influence governments' actions and other individuals' political behaviours, and/or reflecting individuals' interest and psychological involvement in politics". Such a definition covers a wealth of political activities. It includes, as per Verba, et al.'s (1995) conceptualisation, mobilisation activities oriented to governments, but in line with the notions of lifestyle politics and communication activities, it also embraces more personalised and communicative forms of political participation (e.g., consumption of political information or political consumerism).

\section{The debate between Internet optimists, pessimists and normalisers}

As emerged in the previous section, political participation is a widely investigated subject and numerous publications examined the contributions of the Internet to this phenomenon. Within this strand of research it is possible to identify three main schools of thought that have generated a lively academic debate, still very much alive today. At one end of the continuum there are the optimists who speak of mobilisation and argue that the Internet promotes political participation by offering additional and convenient pathways to participation, by generating new forms of political engagement and participation, and by engaging audiences traditionally characterised by 
lower levels of political engagement and activity such as young people, individuals with lower socio-economic status or isolated citizens (Bengstsson and Christensen, 2012; Borge and Cardenal, 2010; Boulianne, 2009; Delli Carpini, 2000; Gibson, et al., 2005; Hamilton and Tolbert, 2012; Johnson and Kaye, 2003; Kavanaugh, et al., 2008; Kim and Kim, 2007; Krueger, 2002; Morris and Morris, 2013; Rojas and Puig-i-Abril, 2009; Tolbert and McNeal, 2003; Ward, et al., 2003).

An example of a study endorsing the optimists' stance is that of Bengstsson and Christensen (2012) who, focusing on the case of Finland, established that the Internet helped to mobilise a considerable size of the population not engaged in politics. Hamilton and Tolbert (2012) confirmed the mobilising potential of the Internet and suggested that online information gathering and participation may influence political participation and engagement also for those citizens who are uninterested in politics, with the Internet leading in certain cases to accidental mobilisation. The role of information as a mobilisation agent for audiences characterised by limited levels of political activity has been also highlighted by Rojas and Puig-i-Abril (2009), who found that digital technologies offered additional pathways to information stimulating political behaviours in the offline domain. Similarly, Morris and Morris (2013) showed that in the early stages of the 2012 American presidential campaign greater levels of access to the Internet were associated to greater political knowledge and engagement for individuals with low socio-economic status. They attributed this link to the incidental learning occurring during high-profile political events.

At the other end of the continuum, there are the pessimists who describe the Internet as a distracting medium which can contribute to civic decline by inducing citizens to engage in Web activities and taking them away from more meaningful forms of participation (Nisbet and Scheufele, 2004; Scheufele and Nisbet, 2002; Zhang and Chia, 2006). This perspective has been inspired by Putnam's $(1995,2000)$ work on social capital. Putnam (2000) documented the erosion of social capital, which refers to "connections among individuals - social networks and the norms of reciprocity and trustworthiness that arise from them" [ㄷ]], in the American society over the last few decades. Putnam (2000) argued that this decline was associated with a growth in the viewing of entertainment TV which displaced time that could be invested in civic or political activities. Several authors applied the time displacement hypothesis to the online environment, and suggested that the Internet generated passivity by absorbing energies that citizens would, otherwise, invest in political or civic activities (Diani, 2001; Kraut, et al., 1998; Lusoli and Ward, 2004; Nie and Erbring, 2002; Rash, 1997; Turkle, 1996). This notion has informed the pessimists' stance.

Finally, there is a third school of thought whose advocates are referred to in the academic literature as normalisers. The normalisers paint a picture in which the Internet has supplementary effects on political participation and engagement reinforcing current participatory trends by aiding those citizens already interested in politics (Calenda and Meijer, 2009; Calenda and Mosca, 2007; Dutta-Bergman and Chung, 2005; Kenski and Stroud, 2006; Kim, 2006; Krueger, 2002; Moy, et al., 2005; Norris, 2001, 2002; Polat, 2005; Wang, 2007). Online political activities are perceived in this sense as an extension of off-line ones (Calenda and Mosca, 2007), with the Internet, rather than operating as a game-changing technology, simply providing politically interested citizens with further ways to engage and participate (Tedesco, 2004). In the normalisers' conception even if the Internet has, in part, transformed the way of doing politics, it did not change who participates in politics (Bimber, 2003). Among this group of scholars there are academics who perceive the reinforcement role of the Internet in a negative light. They believe that, by strengthening existing patterns of political engagement and participation, the Internet fortifies established power structures and widens the knowledge gap between politically active and less active citizens making the rich richer and the poor poorer (Bimber, 2001, 2003: Bonfadelli, 2002; Brundidge and Rice, 2009; Delli Carpini and Keeter, 1993; Lindner and Riehm, 2011; Schlozman, et al., 2010; Tedesco, 2004; Weber, et al., 2003).

A similar mixed picture emerged in relation to the contributions of SNSs to political participation. SNSs can be described as "Web-based services that allow individuals to (1) construct a public or semi-public profile within a bounded system, (2) articulate a list of other users with whom they share a connection, and (3) view and traverse their list of connections and those made by others within the system" (boyd and Ellison, 2007), and in recent years many investigations have examined their impact on political campaigning, engagement and participation (Ancu and Cozna, 2009; Gustafsson, 2012; Holt, et al., 2013; Kim and Geidner, 2008; Marichal, 2013; Mascheroni, 2012; Vitak, et al., 2011; Warren, et al., 2014; Xenos, et al., 2014). This type of enquiry has further flourished with the explosion of the Arab Spring, a pro-democracy wave of rebellions occurred in the Arab world between the end of 2010 and 2011, and SNSs have become a hot topic in academia (Khamis and Vaughn, 2012; Lim, 2012; Papacharissi and de Fatima Oliveira, 2011; Tufekci and Wilson, 2012; Wulf, et al., 2013). As said, similarly to what has emerged for the Internet, research has produced contrasting evidence also in relation to the impact of SNSs on political participation. Some scholars stress the positive impact of SNSs on political activity whereas others minimise their mobilising capability, emphasising their tendency to reinforce existing participatory patterns or highlighting their limited or even negative influence on political participation.

A pioneering study within this subject area it was that of Williams and Gulati (2007) who, investigating the relation between candidates' number of Facebook friends and vote shares in 2006 U.S. midterm elections, established that Facebook support has a significant effect on 
candidates' final vote shares and that SNSs are capable of affecting the electoral process. However, a limitation of Williams and Gulati's study is that they focused exclusively on the aggregate level without examining and explaining the processes behind users' voting behaviour. Their approach has been criticised by Kim and Geidner (2008) who attempted to fill this gap and indicated that SNSs usage enhanced voting probability by increasing individual and collective voting rewards such as social capital, civic duty and political efficacy, and that these platforms were particularly relevant for young voters who are, in general, relatively alienated from politics. These two investigations identified a positive relationship between SNSs usage and voting but, by concentrating solely on this activity, they left the rest of the political participation spectrum untouched. Other more comprehensive enquiries confirm that SNSs can aid citizens' political participation (Gil de Zúñiga, et al., 2012; Halpern and Lee, 2011; Holt, et al., 2013; Tang and Lee, 2013; Towner, 2013; Xenos, et al., 2014). Replicating what Bachman, et al. (2010) find in relation to online media in general, Holt, et al. (2013), Towner (2013) and Xenos, et al. (2014) provide evidence in support of the mobilisation hypothesis and argue that SNSs could serve as a leveller of political participation between younger and older citizens as youths' high usage of SNSs can compensate their limited usage of traditional media for obtaining political information.

In contrast to these findings, there are other studies which painted a picture of limited or even negative effects of SNSs on political participation (Ancu and Cozna, 2009; Baumgartner and Morris, 2010; Fenton and Barassi, 2011; Valenzuela, et al., 2009). In their study exploring the reasons why members of the public visited MySpace profiles of 2008 U.S. primary candidates, Ancu and Cozna (2009) determined that users were attracted to MySpace mainly because they desired social interaction with other like-minded individuals, a type of usage negatively related to campaign involvement. Fenton and Barassi (2011) provided an interesting explanation of the negative influence that SNSs can have on political participation. They contended that in assessing the political potential of SNSs differences between individual and collective forms of participation have to be considered as SNSs tend to promote individualism and personal affairs disconnecting individuals from the public terrain of political participation and guiding them away from the communality of collective political endeavour in favour of the personal politics of selfpresentation. Other authors such as Baumgartner and Morris (2010) and Valenzuela, et al. (2009) rejected the idea that SNSs affect negatively political participation, suggesting, in stead, that these platforms have limited or no effects on political participation. Baumgartner and Morris (2010) found that SNSs did not increase political interest and participation among young people who employed these platforms mainly to seek out supporting views. Similarly, focusing on the case of Facebook, Valenzuela, et al. (2009) stressed the limited contributions of SNSs to youths' political participation and argued that these platforms are not the most effective tool to counteract youths' political disengagement.

Finally, there are a number of other investigations which backed up the normalisers' stance and established that politically engaged individuals get the most from SNSs (Carlisle and Patton, 2013; Gustafsson, 2012; Mascheroni, 2012; Rainie and Smith, 2012; Vesnic-Alujevic, 2012; Vitak, et al., 2011). Focusing on Facebook, Carlisle and Patton (2013) found that during the 2008 primary and general elections people showed a limited engagement in political activity via Facebook and that political interest strongly influenced Facebook political participation. In line with these findings there are also the investigations by Vesnic-Alujevic (2012) and Gustafsson (2012). The first indicated that the more people were involved in politics off-line the more they participated politically through their Facebook profile pages. Similarly, Gustafsson (2012) revealed that members of interest organisations considered SNSs valuable tools for participation, while non-members generally refrained from sharing political views with their friends and, despite being exposed to political content and requests for participation, preferred to remain passive. Finally, there is Vitak, et al.'s (2011) study which is arguably one of the most comprehensive efforts in SNSs and political participation research. Vitak, et al. (2011) established that Facebook can provide young people with a space to express their political opinions, to search for political information, and to engage in political discussions. They recognised the potential of this specific SNS as a political tool but, at the same time, stressed the strong link between Facebook political activity, political interest and off-line political participation. In this sense, their research can be placed in the normalisers' group, suggesting that those who are already politically engaged seek multiple outlets for their political behaviours and that SNSs alone do not drive previously inactive individuals to political participation.

This section has stressed that there is no general scholarly agreement on the capability of the Internet and SNSs to promote citizens' political participation. Three schools of thought have emerged in relation to this topic: the optimists who suggested that digital technologies can engage new audiences and generate new forms of participation; the pessimists who argued that online platforms draw citizens away from more meaningful political activities or have a limited effect on participation; and the normalisers who believed that the internet and SNSs strengthen existing participatory patterns. The latter stance has found the most support in the literature but there is no conclusive evidence in its favour. This contrasting picture calls for a further review of the studies falling within this strand of research.

Two assumptions in Internet and political participation research 
Several factors could contribute to the mixed picture produced by optimists, pessimists and normalisers. The national contexts where the various studies are carried out could, for instance, influence their findings, a thesis supported by Anduiza, et al. (2012) who established that contextual elements such as digital divides, media systems, and institutional settings mediate the relationship between digital media and political participation. Another explanation could be the different ways in which researchers have operationalised political participation and Internet/SNSs usage in their investigations. Such a hypothesis is explored in this section through a critical review of research assessing the contributions of the Internet and SNSs to political participation.

A total of 60 studies were included in the review. Investigations which examined specifically the effects of Internet and SNSs usage on citizens' political participation, entailed the analysis of primary or secondary data, and focused on more than one political activity were considered. On the other hand, non-English language papers, studies based on reviews of the academic literature (e.g., Rash, 1997; Tedesco, 2004), focusing on political institutions and parties (e.g., Gibson, et al., 2005; Lusoli and Ward, 2004), and examining only civic participation (e.g., Nie and Erbring, 2002) or one political activity (e.g., Marichal, 2013; Williams and Gulati, 2007) were excluded.

The studies were selected through a three-step search process, first conducted in November 2013, and then updated in May 2014. In the first step, a search was conducted on six online databases: ACM Digital Library; EBSCO; ProQuest Central; ScienceDirect; Social Science Research Network; and Google Books. The following keywords were used in different combinations: 'Internet'; 'social networking website'; 'social networks'; 'digital media'; 'new media'; 'politics; political'; 'participation'; 'communication'; 'mobilization'; 'activism';

'information'; 'discussion'; 'citizens'; 'use'; 'usage'; 'effect'; and 'impact'. 'Next, the reference lists of relevant articles found in the first stage were reviewed. Finally, key journals were identified, and a last search employing the above keywords was carried out through their Web sites.

The investigations examined in this review were classified according to their findings (i.e., mobilisation, reinforcement, and negative or limited effects) as displayed in Table 1. 
Table I: Effects of Internet and SNS Usage on Political Participation

\begin{tabular}{|c|c|c|}
\hline Reinforcement effect & Mobilisation effect & Negative or limited effect \\
\hline $\begin{array}{l}\text { Bimber, 2001, 2003 } \\
\text { Brundidge and Rice, } 2009 \\
\text { Calenda and Meijer, } 2009 \\
\text { Calenda and Mosca, } 2007 \\
\text { Cantijoch, 2012* } \\
\text { Carlisle and Patton, } 2013 \\
\text { Dutta-Bergman and Chung, } \\
2005 \\
\text { Gibson and Cantijoch, 2013* } \\
\text { Gustafsson, 2012 } \\
\text { Hargittai and Shaw, 2013* } \\
\text { Kenski and Stroud, } 2006 \\
\text { Kim, 2006 } \\
\text { Krueger, 2006 } \\
\text { Lindner and Riehm, 2011 } \\
\text { Mascheroni, 2012 } \\
\text { Moy et al., 2005 } \\
\text { Norris, 2001 } \\
\text { Oser et al., 2013*} \\
\text { Polat, 2005 } \\
\text { Quintelier and Visser, 2008* } \\
\text { Rainie and Smith, } 2012 \\
\text { Schlozman et al., 2010 } \\
\text { Storsul, 2011 } \\
\text { Vaccari, 2012* } \\
\text { Vesnic-Alujevic, 2012 } \\
\text { Vitak et al., 2011 } \\
\text { Wang, 2007 } \\
\text { Weber ot al 2003 }\end{array}$ & $\begin{array}{l}\text { Bakker and de Vreese 2011* } \\
\text { Bengtsson and Cristensen, } \\
2012 \\
\text { Borge and Cardenal, } 2010 \\
\text { Boullianne, 2009 } \\
\text { Cantijoch, 2012* } \\
\text { Gibson and Cantijoch, 2013* } \\
\text { Gibson et al., 2005 } \\
\text { Gil de Zúñiga et al., 2012 } \\
\text { Halpern and Lee, 2011 } \\
\text { Hamilton and Tolbert, } 2012 \\
\text { Hargittai and Shaw, } 2013^{*} \\
\text { Holt et al., 2013 } \\
\text { Johnson and Kaye, 2003 } \\
\text { Kavanaugh et al., 2008 } \\
\text { Kim and Kim, 2007 } \\
\text { Krueger, 2002 } \\
\text { Kruikemeier et al., 2013 } \\
\text { Morris and Morris, } 2013 \\
\text { Oser et al., 2013* } \\
\text { Quintelier and Visser, } 2008^{*} \\
\text { Rice et al., 2013 } \\
\text { Rojas and Puig-i-Abril, } 2009 \\
\text { Tang and Lee, 2013 } \\
\text { Tolbert and McNeal, } 2003 \\
\text { Towner, 2013 } \\
\text { Vaccari, 2012* } \\
\text { Ward et al., 2003 } \\
\text { Xenos et al. 2014 }\end{array}$ & $\begin{array}{l}\text { Ancu and Cozna, } 2009 \\
\text { Bakker and de Vreese 2011* } \\
\text { Baumgartner and Morris, } \\
2010 \text { Fenton and Barassi, } \\
2011 \\
\text { Jennings and Zeitner, } 2003 \\
\text { Nisbet and Scheufele 2004 } \\
\text { Quintelier and Visser, 2008* } \\
\text { Scheufele and Nisbet, } 2002 \\
\text { Zhang and Chia, 2006 } \\
\text { Valenzuela et al., } 2009\end{array}$ \\
\hline
\end{tabular}

*Multiple effects found

\begin{abstract}
The considered studies focused either on the Internet or SNSs. The great majority examined both mobilisation (i.e., aiming to influence governments) and communication (i.e., reflecting individuals' interest and psychological involvement in politics) activities. Single dimension studies were scarce: two for the communication dimension (Brundidge and Rice, 2009; Dutta-Bergman and Chung, 2005), and nine for the mobilisation dimension (Gil de Zúñiga, et al., 2012; Halpern and Lee, 2011; Johnson and Kaye, 2003; Kenski and Stroud, 2006; Krueger, 2002, 2006; Lindner and Riehm, 2011; Oser, et al., 2013; Rice, et al., 2013).

An interesting element emerging from Table 1 is the presence of studies supporting more than one stance (Bakker and de Vreese, 2011; Cantijoch, 2012; Gibson and Cantijoch, 2013; Hargittai and Shaw, 2013; Oser, et al., 2013; Quintelier and Visser, 2008; Vaccari, 2012). To shed light on this matter it was considered whether or not the reviewed investigations distinguished between types of political activities and various Internet/SNSs usage practices (e.g., information, entertainment, etc.) when discussing the contributions of digital technologies to political participation.
\end{abstract}


Table II: Distinction Between Different Forms of Political Participation and Internet/SNSs Usage Practices

\begin{tabular}{|c|c|}
\hline $\begin{array}{c}\text { Distinguished between different forms of } \\
\text { political participation }\end{array}$ & $\begin{array}{c}\text { Considered different Internet/SNSs } \\
\text { usage practices }\end{array}$ \\
\hline $\begin{array}{l}\text { Calenda and Mosca, } 2007 \\
\text { Cantijoch, } 2012 \\
\text { Carlisle and Patton, } 2013 \\
\text { Fenton and Barassi, } 2011 \\
\text { Gibson and Cantijoch, } 2013 \\
\text { Hargittai and Shaw, } 2013 \\
\text { Johnson and Kaye, } 2003 \\
\text { Kavanaugh et al., } 2008 \\
\text { Nisbet and Scheufele } 2004 \\
\text { Norris, } 2001 \\
\text { Rice et al., } 2013 \\
\text { Rojas and Puig-i-Abril, } 2009 \\
\text { Storsul, } 2011 \\
\text { Tang and Lee, } 2013 \\
\text { Vaccari, } 2012 \\
\text { Vitak et al., } 2011 \\
\text { Wang, } 2007\end{array}$ & $\begin{array}{l}\text { Ancu and Cozna, } 2009 \\
\text { Bakker and de Vreese } 2011 \\
\text { Kim, } 2006 \\
\text { Moy et al., } 2005 \\
\text { Quintelier and Visser, } 2008 \\
\text { Rojas and Puig-i-Abril, } 2009 \\
\text { Scheufele and Nisbet, } 2002\end{array}$ \\
\hline
\end{tabular}

As shown in Table 2, except Oser, et al. (2013), all the authors who found multiple effects had made a distinction between the considered types of political activities and the various ways participants employ digital technologies. This suggests that the contributions of the Internet and SNSs vary according to the different modes of participation and usage practices. Therefore, it can be argued that the different ways in which researchers have operationalised political participation and Internet/SNSs usage have impacted on their findings, and contributed to the contrasting picture produced by optimists, pessimists and normalisers.

By looking at the ways political participation and Internet/SNS usage have been operationalised, two assumptions characterising many Internet, SNSs and political participation studies can be identified. The first assumption relates to the purpose and orientation of political participation which has been often considered as an activity aiming to affect governments' actions, either directly or indirectly. However, as highlighted in the first section of this paper, this conception is too narrow because it excludes more individualised and communicative forms of participation. Political participation is a hydra-headed phenomenon in that it encompasses many different types of activities which, despite falling under the same theoretical umbrella, are very different in terms of the resources they require (e.g., time and skills), their orientation (i.e., government-oriented vs lifestyle politics), and the purposes driving them (i.e., communication vs mobilisation).

Regardless of the complexity of such a phenomenon, as displayed in Table 2, within this specific strand of research only few studies took into consideration the multidimensionality of political participation, with most investigations exhibiting an inclination, often found in academia, towards generalisation rather than specification. A distinction has been often made between off-line and online participation (e.g., Boulianne, 2009; Jennings and Zeitner, 2003), or between traditional and non-traditional participation (e.g., Kruikemeier, et al., 2013; Schlozman, et al., 2010;

Towner, 2013). However, in most cases, the differences between the considered activities are not taken into account when assessing the contributions of digital technologies. The limitations of such an approach appear evident when looking at investigations which did the opposite. These studies, in fact, highlighted that the impact of the Internet and SNSs varied in relation to different political activities. For instance, Kavanaugh, et al. (2008) showed that citizens with medium/low levels of political engagement participated much less than politically active citizens in online formal political activities such as contacting public officials or contributing campaign donations. However, both groups displayed similar levels of participation with regards to news consumption or political discussion. Nisbet and Scheufele (2004) also emphasised how the effects of the Internet on political participation change in relation to the various political activities. They found that Internet usage had a limited impact on campaign participation while it was positively related 
to the exposure and consumption of campaign information. In line with the communication/mobilisation distinction adopted in this paper, Gibson and Cantijoch (2013) identified two dimensions of political participation: participation and passive engagement. The first encompasses six modes of participation (i.e., voting, party/campaign activities, protest activities, contacting, communal and consumerism) while the second dimension includes three modes of participation (i.e., news attention, discussion, expressive activities). They proved that off-line activities falling within the first dimension were replicated online, whereas with regards to more passive modes of engagement new forms of participation emerged. Vaccari (2012) also emphasised the risks of oversimplification associated with a one-size-fits-all approach and, in relation to the links between off-line and online participation, showed that individuals involved in more demanding off-line forms of participation such as attending rallies engaged in similar activities also online, while people limiting their engagement to the consumption of political information on mass media replaced, at least partially, TV with online sources.

With respect to SNSs, Storsul (2011) revealed that these platforms were the main instrument that politically engaged youths employed for organising and coordinating political activities. At the same time, Storsul also indicated that young people were hesitant to use SNSs for political deliberation as they were concerned about the way they presented themselves and did not want to appear very political. However, these findings were not confirmed by Vitak, et al. (2011) who showed that young people engaged on Facebook mostly in activities falling within the communication dimension of political participation like expressing political opinions. This inconsistency could be explained with the fact that Storsul (2011) focused on politically active youths, while Vitak, et al. (2011) concentrated on young people in general. These two different groups may, therefore, use SNSs in different ways, with the firsts taking advantage of the mobilisation affordances of these online platforms, while the seconds limiting their participation to communication-related activities.

Considerations on the different uses of digital tools lead to the second assumption characterising many Internet and political participation studies, an assumption that may also play a part in the mixed picture emerged so far. The second assumption is the over-generalised conceptualisation of the Internet, with academics often speaking of Internet effects, ignoring the differences between various online tools and how people employ them. In this sense, Dimitrova, et al. (2014) argued that it is a mistake to think in terms of general influence as the effects can vary across different digital tools. Accordingly, they found that while the political use of social media was a strong predictor of political participation, the usage of online news sites seemed to have no effect on participation. Similarly, Yoo and Gil de Zúñiga (2014) stressed the value of such a differential approach and established that Facebook and blogs have different qualities as news media, with the first amplifying inequalities between people with different socioeconomic status, and blogs use associated with an increase in less-educated participants' political knowledge.

However, distinguishing between the various online tools is only the first step to achieve a deeper understanding of how digital technologies can contribute to political participation. The analysis of studies examining different Internet/SNSs usage practices demonstrates the limited explanatory power of the online/offline distinction in assessing a complex phenomenon such as political participation. Also, as highlighted by Moy, et al. (2005) and Tang and Lee (2013), it shows the need for an approach which will take into account the different patterns in Internet and SNSs usage. In relation to the specific case of SNSs, in a report of the Pew Research Center, Hampton, et al. (2011) explained that there is a great deal of variation in how people use SNSs with usage practices varying according to the types of person and SNSs. These platforms can be employed for relational maintenance (Lampe, et al., 2006; Raacke and Bonds-Raacke, 2008), to establish, to present, and to negotiate identity (Liu, 2007), for social surveillance (Joinson, 2008), and to share information and be entertained (Waters and Ackerman, 2011).

Regrettably, only a limited number of studies examined how different usage practices (e.g., information seeking, entertainment, etc.) can influence political participation (Ancu and Cozna, 2009; Bakker and de Vreese, 2011; Gil de Zúñiga, et al., 2012; Kim, 2006; Kruikemeier, et al., 2013; Moy, et al., 2005; Quintelier and Visser, 2008; Rojas and Puig-i-Abril, 2009; Scheufele and Nisbet, 2002; Tang and Lee, 2013). In relation to the various usages of the Internet, Scheufele and Nisbet (2002), Rojas and Puig-i-Abril (2009) and Bakker and de Vreese (2011) found that employing this medium for entertainment purposes can contribute negatively to political efficacy, knowledge and participation, while informational usage tend to be positively related to such variables. In line with these studies, Kim (2006) argued that the political consequences of the Internet depend on the way the medium is employed and he determined that e-social capital (Hopkins and Tomas, 2004) did not enhance civic participation in politics while e-deliberation increased political interest and participation in online political protests. In addition, Kim (2006) corroborated one of Quintelier and Visser's (2008) findings, namely the positive influence that e-shopping can have on political participation, and observed that this specific use of the online medium tend to be positively related to participation in online political protests, despite having no relationship with political interest. This last result provided an interesting contribution to the debate between Internet optimists, pessimists and normalisers as it indicated that some Internet praxes can lead to an increase in particular forms of political participation independently from individuals' levels of political engagement.

Focusing on SNSs, Ancu and Cozna (2009) showed that campaign involvement was negatively related to the use of MySpace for social interaction and not related to the use of MySpace for 
information seeking and entertainment purposes. These results did not corroborate the positive impact of informational usage on political participation. This could be due to the fact that Ancu and Cozna (2009) focused on a very specific type of political activity, campaign involvement, and SNS, MySpace. Instead, the positive link between informational uses of SNSs and political participation has been emphasised by Gil de Zúñiga, et al. (2012) and Tang and Lee (2013), who also highlighted that the impact of information was mediated by network size and heterogeneity. These studies confirmed the worth of considering different Internet and SNSs' practices in assessing the influence of these technologies on political participation. This argument has been perfectly summarised by Papacharissi (2009) who observed that the Internet is a tool which does not present in itself the capability to bring social change and that its impact on society, so as its potential to empower or restricts individuals, rests upon the ways in which it is used.

A critical review of the academic literature assessing the contributions of the Internet and SNSs to political participation, suggested that two assumptions characterising many investigations falling within this strand of research prevented academics from shedding light on the capability of digital technologies to promote citizens' political participation. The two identified assumptions are surely not the only ones that can be found in Internet and political participation studies (e.g., positive connotation attributed to political participation), but they emerge as the most likely ones to account for the mixed picture produced by Internet optimists, normalisers and pessimists.

The first assumption is the consideration of political participation as a set of government-oriented activities and the consequent overlooking of the communication dimension of this hydra-headed phenomenon. Such a notion has arguably prevented scholars from looking at how the influence of the Internet and SNSs can vary according to the type of participatory activity. A considerable number of the studies recognising the multidimensionality of political participation distinguished between mobilisation-related activities and communication-oriented ones, validating the conceptualisation of political participation adopted in this paper. They suggested that the Internet and SNSs tend to support mainly communication activities with regards to the general public, while more politically active citizens are likely also to take advantage of the mobilising potential of these technologies.

The second assumption is the perception of the Internet as a homogeneous platform and of Internet usage as a uniform practice, with numerous academics speaking generally of Internet effects. This over-generalised conceptualisation of Internet usage has, in turn, led researchers to concentrate on the online/off-line distinction and to overlook the impact of different Internet and SNSs usage practices. In relation to the various ways individuals can employ these technologies research which went beyond the simplistic online/off-line distinction proposed that usage per se does not enhance political participation. It argued that different usage practices generate different effects, with informational uses promoting participation and entertainment uses inhibiting it.

\section{Conclusion: The need for a differential approach}

A careful review of the literature on the impact of the Internet and SNSs on political participation highlighted that the contributions of digital technologies vary in relation to different political activities and usage practices. What has come into light from this paper calls for a shift in the ways academics look at the links between political participation, the Internet and SNSs. As stressed by several scholars, the debate among normalisers, optimists and pessimists arised from the older dichotomy between social determinism and technological determinism (Chadwick, 2006; Anstead and Chadwick, 2009; Calenda and Mejer, 2009). From a social determinist perspective (i.e., normalisers), social and political institution determine the impact of technology, while from a techno-deterministic perspective (i.e., optimists and pessimists), society and politics are shaped by technology. This dichotomous approach has been often applied to Internet and political participation research and it has limited the understanding of the political affordances of such a medium. Given that empowering aspects (e.g., increased access to information can lead to a more informed citizenry) and limitations of this technology (e.g., information overload and tendencies to political polarisation) can be identified, Breindl (2010) stressed the need to go over such a binary division and to interpret the effects of the Internet on political participation as part of a continuum.

In this sense it would be beneficial for the development of this subject area the adoption of a more differential approach through which considering the effects of digital technologies on political participation. In order to do so, firstly, a distinction has to be made between the different modes of participation. In this paper political participation has been described as a set of activities influencing or aiming to influence governments' actions and/or other individuals' political behaviours and/or reflecting individuals' interest and psychological involvement in politics. Such a theorisation encompasses both the mobilisation - influencing or aiming to influence governments' actions and other individuals' political behaviours - and communication dimensions of political participation - reflecting individuals' interest and psychological involvement in politics - and it could be a valuable framework for approaching this phenomenon. 
Secondly, the various Internet usage practices have to be considered in order to fully asses the impact of the Internet on political participation. Scholars have developed numerous classifications of Internet usages (Kraut, et al., 1998; Shah, et al., 2001; Katz, et al., 2001; Nie and Erbring, 2002; Moy, et al., 2005; Wang, 2007; Foot, et al., 2009). Their classifications can help in the development of a comprehensive categorisation of the various non-political usages of Internet and SNSs. A possible classification could distinguish, for instance, between three usage dimensions: the information dimension including activities such as news consumptions; the interpersonal communication dimension encompassing activities such as contacting family and friends; and the social recreation dimension embracing activities such as gaming.

The mobilisation/communication theorisation of political participation and the categorisation of Internet and SNSs usages based on the information, the interpersonal communication, and the social recreation dimensions are two examples of differential approaches applied to the Internet and political participation research. These ways of operationalising political participation and Internet usage could be an interesting point of departure to move away from the polarised debate between optimists, pessimists and normalisers and favour the development of the field. FM

\section{About the author}

Paolo Casteltrione has a bachelor's degree in communication sciences and an honours degree in communication, advertising and PR, obtained respectively at the Universitá Suor Orsola Benincasa (2007) and Edinburgh Napier University (2009). Since September 2010 he is a Ph.D. student at Queen Margaret University and he is now in the final year of his doctorate. His research project investigates the impact of Facebook on citizens' political participation in Italy and United Kingdom. In particular, it aims to establish how different forms of political participation (mobilisation vs. communication activities) have been influenced by the rise of this social networking Web site and whether such a technology is able to promote the participation of citizens with limited levels of political engagement and participation. Paolo's main research interests include social media, the Internet and information, media and political communication, and citizens' political behaviours.

E-mail: icasteltrione [at] qmu [dot] ac [dot] uk

\section{Notes}

1. Fischer, 2003, p. 205.

2. Norris, 2007, p. 629.

3. Verba, et al., 1995, p. 38.

4. Bennett, 2004, p. 104.

5. Putnam, 2000, p. 19.

\section{References}

Monica Ancu and Raluca Cozma, 2009. "MySpace politics: Uses and gratifications of befriending candidates," Journal of Broadcasting \& Electronic Media, volume 53, number 4, pp. 567-583. doi: http://dx.doi.org/10.1080/08838150903333064, accessed 20 February 2015.

Eva Anduiza, Michael J. Jensen, and Laia Jorba (editors), 2012. Digital media and political engagement worldwide: A comparative study. Cambridge: Cambridge University Press.

Eva Anduiza, Marta Cantijoch, and Aina Gallego, 2009. "Political participation and the Internet: A field essay," Information, Communication \& Society, volume 12, number 6, pp. 860-878. doi: http://dx.doi.org/10.1080/13691180802282720, accessed 20 February 2015.

Nick Anstead and Andrew Chadwick, 2009. "Parties, election campaigning, and the internet: Towards a comparative institutional approach," In: Andrew Chadwick and Philip N. Howard (editors). Routledge handbook of Internet politics, London: Routledge, pp. 56-71.

Tom P. Bakker and Claes H. de Vreese, 2011. "Good news for the future? Young people, Internet use, and political participation," Communication Research, volume 38, number 4, pp. 451-470. doi: http://dx.doi.org/10.1177/0093650210381738, accessed 20 February 2015.

Jody C. Baumgartner and Jonathan S. Morris, 2010. "MyFaceTube politics: social networking Web sites and political engagement of young adults," Social Science Computer Review, volume 28, number 1 , pp. 24-44.

doi: http://dx.doi.orq/10.1177/0894439309334325, accessed 20 February 2015.

Nancy K. Baym, 2010. Personal connections in the digital age. Cambridge: Polity. 
Åsa Bengstsson and Henrik S. Christensen, 2012. "The political competence of Internet participants: Evidence from Finland," In: Brian D. Loader and Dan Marcea (editors). Social media and democracy: Innovations in participatory politics. London: Routledge, pp. 131-149.

W. Lance Bennett, 2004. "Branded political communication: Lifestyle politics, logo campaigns and the rise of global citizenship," In: Michele Micheletti, Andreas Follesdal, and Dietlind Stolle (editors). Politics, products, and markets: Exploring political consumerism past and present. New Brunswick, N.J.: Transaction, pp. 101-126.

W. Lance Bennett, 1998. "The uncivic culture: Communication, identity, and the rise of lifestyle politics," PS: Political Science \& Politics, volume 31, number 4, pp. 741-761. doi: http://dx.doi.org/10.1017/S1049096500053270, accessed 20 February 2015.

W. Lance Bennett and Shanto Iyengar, 2008. "A new era of minimal effects? The changing foundations of political communication," Journal of Communication, volume 58, number 4, pp. 707-731. doi: http://dx.doi.org/10.1111/i.1460-2466.2008.00410.x, accessed 20 February 2015.

Bruce Bimber, 2003. Information and American democracy: Technology in the evolution of political power. New York: Cambridge University Press.

Bruce Bimber, 2001. "Information and political engagement in America: The search for effects of information technology at the individual level," Political Research Quarterly, volume 54, number 1 , pp. 53-67.

doi: http://dx.doi.org/10.1177/106591290105400103, accessed 20 February 2015.

Heinz Bonfadelli, 2002. "The Internet and knowledge gaps: A theoretical and empirical investigation," European Journal of Communication, volume 17, number 1, pp. 65-84. doi: http://dx.doi.org/10.1177/0267323102017001607, accessed 20 February 2015.

Rosa Borge and Ana S. Cardenal, 2010. "Surfing the Net: A pathway to political participation without motivation?" paper presented at Internet, politics, policy 2010: An impact assessment (Oxford), at http://ipp.oii.ox.ac.uk/2010/programme-2010/tracks-34-policy/panel-3bparticipation-in-politics-and/borge-cardenal-surfing-the-net-a-pathway, accessed 5 November 2013.

Shelley Boulianne, 2009. "Does Internet use affect engagement? A meta-analysis of research," Political Communication, volume 26, number 2, pp. 193-211.

doi: http://dx.doi.org/10.1080/10584600902854363, accessed 20 February 2015.

danah boyd and Nicole B. Ellison, 2007. "Social network sites: Definition, history, and scholarship," Journal of Computer-Mediated Communication, volume 13, number 1, pp. 210-230. doi: http://dx.doi.org/10.1111/i.1083-6101.2007.00393.x, accessed 20 February 2015.

Yana Breindl, 2010. "Critique of the democratic potentialities of the Internet: A review of current theory and practice," tripleC, volume 8 , number 1 , at http://www.triple-c.at/index.php/tripleC/article/view/159, accessed 6 November 2013.

Jennifer Brundidge and Ronald E. Rice, 2009. "Political engagement online: Do the information rich get richer and the like-minded more similar?" In: Andrew Chadwick and Philip N. Howard (editors). Routledge handbook of Internet politics. London: Routledge, pp. 144-156.

Davide Calenda and Albert Meijer, 2009. "Young people, Internet and political participation: Findings of a Web survey in Italy, Spain and The Netherlands," Information, Communication \& Society, volume 12 , number 6 , pp. 879-898. doi: http://dx.doi.org/10.1080/13691180802158508, accessed 20 February 2015.

Davide Calenda and Lorenzo Mosca, 2007. "The political use of the Internet: Some insights from two surveys of Italian students," Information, Communication \& Society, volume 10, number 1 , pp. 29-47.

doi: http://dx.doi.org/10.1080/13691180701193028, accessed 20 February 2015.

Marta Cantijoch, 2012. "Digital media and offline political participation in Spain," In: Eva Anduiza, Michael J. Jensen, and Laia Jorba (editors). Digital media and political engagement worldwide: A comparative study. Cambridge: Cambridge University Press, pp. 118-137.

Juliet E. Carlisle and Robert C. Patton, 2013. "Is social media changing how we understand political engagement? An analysis of Facebook and the 2008 Presidential election," Political Research Quarterly, volume 66, number 4, pp. 883-895. doi: http://dx. doi.org/10.1177/1065912913482758, accessed 20 February 2015.

Andrew Chadwick, 2006. Internet politics: States, citizens, and new communication technologies. Oxford: Oxford University Press.

Andrew Chadwick and Philip N. Howard (editors), 2009. Routledge handbook of Internet politics. London: Routledge. 
Carol A. Christy, 1987. Sex differences in political participation: Processes of change in fourteen nations. New York: Praeger.

Russell J. Dalton, 2004. Democratic challenges, democratic choices: The erosion of political support in advanced industrial democracies. New York: Oxford University Press.

Michael X. Delli Carpini, 2000. "Gen.com: Youth, civic engagement, and the new information environment," Political Communication, volume 17, number 4, pp. 341-349. doi: http://dx.doi.org/10.1080/10584600050178942, accessed 20 February 2015

Michael X. Delli Carpini and Scott Keeter, 1993. "Measuring political knowledge: Putting first things first," American Journal of Political Science, volume 37, number 4, pp. 1,179-1,206. doi: http://dx.doi.org/10.2307/2111549, accessed 20 February 2015.

Mario Diani, 2001. "Social movement networks: Virtual and real," In: Frank Webster (editor). Culture and politics in the information age: A new politics? London: Routledge, pp. 117-128.

Daniela V. Dimitrova, Adam Shehata, Jesper Strömbäck, and Lars W. Nord, 2014. "The effects of digital media on political knowledge and participation in election campaigns: Evidence from panel data," Communication Research, volume 41, number 1, pp. 95-118. doi: http://dx.doi.org/10.1177/0093650211426004, accessed 20 February 2015.

Mohan Dutta-Bergman and Wonjun Chung, 2005. "The relationship between online political participation and traditional political participation: The theory of channel complementarity," paper presented at International Communication Association 2005 annual meeting (New York).

Natalie Fenton and Veronica Barassi, 2011. "Alternative media and social networking sites: The politics of individuation and political participation," Communication Review, volume 14, number 3, pp. 179-196.

doi: http://dx.doi.org/10.1080/10714421.2011.597245, accessed 20 February 2015.

Kirsten Foot, Steven M. Schneider, Michael Xenos, and Meghan Dougherty, 2009. "Candidates' Web practices in the 2002 US House, Senate, and gubernatorial elections," Journal of Political Marketing, volume 8, number 2, pp. 147-167. doi: http://dx.doi.org/10.1080/15377850902813519, accessed 20 February 2015.

Rachel K. Gibson and Marta Cantijoch, 2013. "Conceptualizing and measuring participation in the age of the Internet: Is online political engagement really different to offline?" Journal of Politics, volume 75 , number 3 , pp. 701-716.

doi: http://dx.doi.org/10.1017/S0022381613000431, accessed 20 February 2015.

Rachel K. Gibson, Wainer Lusoli, and Stephen Ward, 2005. "Online participation in the UK: Testing a 'contextualised' model of Internet effects," British Journal of Politics \& International Relations, volume 7, number 4, pp. 561-583. doi: http://dx.doi.org/10.1111/i.1467-856X.2005.00209.x, accessed 20 February 2015.

Homero Gil Zúñiga, Nakwon Jung, and Sebastián Valenzuela, 2012. "Social media use for news and individuals' social capital, civic engagement and political participation," Journal of ComputerMediated Communication, volume 17, number 3, pp. 319-336.

doi: http://dx.doi.org/10.1111/i.1083-6101.2012.01574.x, accessed 20 February 2015.

Nils Gustafsson, 2012. "The subtle nature of Facebook politics: Swedish social network site users and political participation," New Media \& Society, volume 14, number 1, pp. 1,111-1,127. doi: http://dx.doi.org/10.1177/1461444812439551, accessed 20 February 2015.

Daniel Halpern and Sun Kyong Lee, 2011. "Civic participation and social media: Are they bowling together?" paper presented at the APSA 2011 annual meeting, at http://ssrn.com/abstract $=1901898$, accessed 6 November 2013.

Allison Hamilton and Caroline J. Tolbert, 2012. "Political engagement and the Internet in the 2008 U.S. Presidential elections: A panel survey," In: Eva Anduiza, Michael J. Jensen, and Laia Jorba (editors). Digital media and political engagement worldwide: A comparative study. Cambridge: Cambridge University Press, pp. 56-79.

Keith N. Hampton, Lauren Sessions Goulet, Lee Rainie, and Kristen Purcell, 2011. "Social networking sites and our lives," Pew Research Center (16 June), at http://www.pewinternet.org/2011/06/16/social-networking-sites-and-our-lives/, accessed 5 November 2013.

Eszter Hargittai and Aaron Shaw, 2013. "Digitally savvy citizenship: The role of Internet skills and engagement in young adults' political participation around the 2008 Presidential election," Journal of Broadcasting \& Electronic Media, volume 57, number 2, pp. 115-134. doi: http://dx.doi.org/10.1080/08838151.2013.787079, accessed 20 February 2015.

Colin Hay, 2007. Why we hate politics. Cambridge: Polity. 
Kristoffer Holt, Adam Shehata, Jesper Strömbäck, and Elisabet Ljungberg, 2013. "Age and the effects of news media attention and social media use on political interest and participation: Do social media function as leveller?" European Journal of Communication, volume 28, number 1, pp. 19-34.

doi: http://dx.doi.org/10.1177/0267323112465369, accessed 20 February 2015.

Christina Holtz-Bacha, 2004. "Political communication research abroad: Europe," In: Linda L. Kaid (editor). Handbook of political communication research. Mahwah, N.J.: Lawrence Erlbaum Associates, pp. 463-478.

Liza Hopkins and Julian Tomas, 2004. "E-social capital: Building community through electronic networks,rldquo; at http://www.sisr.net/publications/nd hopkins 2.pdf, accessed 5 November 2013.

Thomas J. Johnson and Barbara K. Kaye, 2003. "A boost or a bust for democracy? How the Web influenced political attitudes and behaviors in the 1996 and 2000 Presidential elections," International Journal of Press/Politics, volume 8, number 3, pp. 9-34.

doi: http://dx.doi.org/10.1177/1081180X03008003002, accessed 20 February 2015.

Adam N. Joinson, 2008. "Looking at, looking up or keeping up with people? Motives and uses of Facebook," CHI '08: Proceedings of the SIGCHI Conference on Human Factors in Computing Systems, pp. 1,027-1,036.

doi: http://dx.doi.org/10.1145/1357054.1357213, accessed 20 February 2015.

Sahar Khamis and Katherine Vaughn, 2012. "'We are all Khaled said' The potentials and limitations of cyberactivism in triggering public mobilization and promoting political change," Journal of Arab \& Muslim Media Research, volume 4, numbers 2-3, pp. 145-163. doi: http://dx.doi.org/10.1386/jammr.4.2-3.145 1, accessed 20 February 2015.

Andrea Kavanaugh, B. Joon Kim, Manuel Pérez-Quiñones, Joseph Schmitz, and Philip Isenhour, 2008. "Net gains in political participation: Secondary effects of Internet on community," Information, Communication \& Society, volume 11, number 7, pp. 933-963. doi: http://dx.doi.org/10.1080/13691180802108990, accessed 20 February 2015

Kate Kenski and Natalie J. Stroud, 2006. "Connections between Internet use and political efficacy, knowledge, and participation," Journal of Broadcasting \& Electronic Media, volume 50, number 2, pp. 173-192.

doi: http://dx.doi.org/10.1207/s15506878jobem5002 1, accessed 20 February 2015.

Ji-Young Kim, 2006. "The impact of Internet use patterns on political engagement: A focus on online deliberation and virtual social capital," Information Polity, volume 11, number 1, pp. 35 -49 .

Kyun Soo Kim and Yong-Chan Kim, 2007. "New and old media uses and political engagement among Korean adolescents," Asian Journal of Communication, volume 17, number 4, pp. 342 $-361$.

doi: http://dx.doi.org/10.1080/01292980701636977, accessed 20 February 2015.

Young M. Kim and Nicholas Geidner, 2008. "Politics as friendship: The impact of online socia networks on young voters' political behavior," paper presented at the annual meeting of the International Communication Association (Montreal).

Robert Kraut, Michael Patterson, Vicki Lundmark, Sara Kiesler, Tridas Mukopadhyay, and William Scherlis, 1998. "Internet paradox: Social technology that reduces social involvement and psychological well-being?" American Psychologist, volume 53, number 9, pp. 1,017-1,031. doi: http://dx.doi.org/10.1037/0003-066X.53.9.1017, accessed 20 February 2015.

Brian S. Krueger, 2002. "Assessing the potential of Internet political participation in the United States: A resource approach," American Politics Research, volume 30, number 5, pp. 476-498. doi: http://dx.doi.org/10.1177/1532673X02030005002, accessed 20 February 2015.

Sanne Kruikemeier, Guda van Noort, Rens Vliegenthart, and Claes H de Vreese, 2013. "Unraveling the effects of active and passive forms of political Internet use: does it affect citizens' political involvement?" New Media \& Society, volume 16, number 6, pp. 903-920.

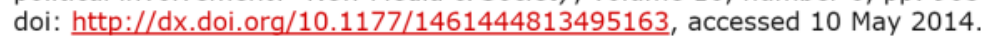

Cliff Lampe, Nicole Ellison, and Charles Steinfield, 2006. "A Face(book) in the crowd: Social searching vs. social browsing," CSCW '06: Proceedings of the 2006 20th Anniversary Conference on Computer Supported Cooperative Work, pp. 167-170.

doi: http://dx.doi.org/10.1145/1180875.1180901, accessed 6 November 2013.

Merlyna Lim, 2012. "Clicks, cabs, and coffee houses: Social media and oppositional movements in Egypt, 2004-2011," Journal of Communication, volume 62, number 2, pp. 231-248. doi: http://dx.doi.org/10.1111/i.1460-2466.2012.01628.x, accessed 6 November 2013. 
Ralf Lindner and Ulrich Riehm, 2011. "Broadening participation through e-petitions? An empirical study of petitions to the German Parliament," Policy \& Internet, volume 3, number 1, pp. 1-23. doi: http://dx.doi.org/10.2202/1944-2866.1083, accessed 10 May 2014

Hugo Liu, 2007. "Social network profiles as taste performances," Journal of Computer-Mediated Communication, volume 13, number 1, pp. 252-275. doi: http://dx.doi.org/10.1111/i.1083-6101.2007.00395.x, accessed 10 May 2014.

Wainer Lusoli and Stephen Ward, 2004. "Digital ranks and file: Activists' perceptions and the use of the Internet," British Journal of Politics \& International Relations, volume 7, number 4, pp. 453 -470 .

doi: http://dx.doi.org/10.1111/i.1467-856X.2004.00150.x, accessed 10 May 2014.

Jose Marichal, 2013. "Political Facebook groups: Micro-activism and the digital front stage," First Monday, volume 18, number 12, and at http://firstmonday.org/article/view/4653/3800, accessed 12 May 2014 doi: http://dx.doi.org/10.5210/fm.v18i12.4653, accessed 20 February 2015

Giovanna Mascheroni, 2012. "Online participation: New forms of civic and political engagement or just new opportunities for networked individualism," In: Brian D. Loader and Dan Marcea (editors). Social media and democracy: Innovations in participatory politics. London: Routledge, pp. 207-223.

David S. Morris and Jonathan S. Morris, 2013. "Digital inequality and participation in the political process: Real or imagined?" Social Science Computer Review, volume 31, number 5, pp. 589 -600 .

doi: http://dx.doi.org/10.1177/0894439313489259, accessed 20 February 2015.

Patricia Moy, Edith Manosevitch, Keith Stamm, and Kate Dunsmore, 2005. "Linking dimensions of Internet use and civic engagement," Journalism \& Mass Communication Quarterly, volume 82, number 3 , pp. 571-586.

doi: http://dx.doi.org/10.1177/107769900508200306, accessed 20 February 2015.

Norman H. Nie and Lutz Erbring, 2002. "Internet and society: A preliminary report," IT\&Society, volume 1 , number 1 , pp. 275-283.

Matthew C. Nisbet and Dietram A. Scheufele, 2004. "Political talk as a catalyst for online citizenship," Journalism \& Mass Communication Quarterly, volume 81, number 4, pp. 877-896. doi: http://dx.doi.org/10.1177/107769900408100410, accessed 20 February 2015.

Pippa Norris, 2011. Democratic deficit: Critical citizens revisited. New York: Cambridge University Press.

Pippa Norris, 2007. "Political activism: New challenges, new opportunities," In: Carles Boix and Susan C. Stokes (editors). Oxford handbook of comparative politics. Oxford: Oxford University Press, pp. 628-652.

doi: http://dx.doi.org/10.1093/oxfordhb/9780199566020.003.0026, accessed 20 February 2015.

Pippa Norris, 2002. Democratic phoenix: Reinventing political activism. New York: Cambridge University Press.

Pippa Norris, 2001. Digital divide: Civic engagement, information poverty, and the Internet worldwide. New York: Cambridge University Press.

Jennifer Oser, Marc Hooghe, and Sofie Marien, 2013. "Is online participation distinct from offline participation? A latent class analysis of participation types and their stratification," Political Research Quarterly, volume 66, number 1, pp. 91-101.

doi: http://dx.doi.org/10.1177/1065912912436695, accessed 20 February 2015.

Zizi Papacharissi (editor), 2011. A networked self: Identity, community and culture on social network sites. New York: Routledge.

Zizi Papacharissi, 2009. "The virtual sphere 2.0: the Internet, the public sphere, and beyond," In: Andrew Chadwick and Philip N. Howard (editors). Routledge handbook of Internet politics. London: Routledge, pp. 230-245.

Zizi Papacharissi and Maria de Fatima Oliveira, 2011. "The rhythms of news storytelling on Twitter: Coverage of the January 25th Egyptian uprising on Twitter," paper presented at the World Association for Public Opinion Research Conference (Amsterdam), at http://tigger. uic.edu/ zizi/Site/Research files/RhythmsNewsStorytellinaTwitterWAPORZPMO.pdf, accessed 13 May 2014.

Susan J. Pharr and Robert D. Putnam (editors), 2000. Disaffected democracies: What's troubling the trilateral countries? Princeton, N.J.: Princeton University Press. 
Rabia K. Polat, 2005. "The Internet and political participation: Exploring the explanatory links," European Journal of Communication, volume 20, number 4, pp. 435-459. doi: http://dx.doi.orq/10.1177/0267323105058251, accessed 20 February 2015.

Robert D. Putnam, 2000. Bowling alone: The collapse and revival of American community. New York: Simon \& Schuster.

Robert D. Putnam, 1995. "Tuning in, tuning out: The strange disappearance of social capital in America," PS: Political Science and Politics, volume 28, number 4, pp. 664-683. doi: http://dx.doi.org/10.2307/420517, accessed 20 February 2015.

John Raacke and Jennifer Bonds-Raacke, 2008. "MySpace and Facebook: Applying the uses and gratifications theory to exploring friend-networking sites," CyberPsychology \& Behavior, volume 11 , number 2, pp. 169-174.

doi: http://dx.doi.org/10.1089/cpb.2007.0056, accessed 20 February 2015.

Lee Rainie and Aaron Smith, 2012. "Politics on social networking sites," Pew Research Center (4 September), at http://www. pewinternet.org/2012/09/04/politics-on-social-networking-sites/, accessed 7 November 2013.

Wayne Rash, 1997. Politics on the nets: Wiring the political process. New York: W.H. Freeman.

Laurie L. Rice, Kenneth W. Moffett, and Ramana Madupalli, 2013. "Campaign-related social networking and the political participation of college students," Social Science Computer Review, volume 31 , number 2 , pp. 257-279.

doi: http://dx.doi.org/10.1177/0894439312455474, accessed 20 February 2015.

Hernando Rojas and Eulalia Puig-i-Abril, 2009. "Mobilizers mobilized: Information, expression, mobilization and participation in the digital age," Journal of Computer-Mediated Communication, volume 14 , number 4 , pp. 902-927. doi: http://dx.doi.org/10.1111/i.1083-6101.2009.01475.x, accessed 20 February 2015.

Dietram A. Scheufele and Matthew C. Nisbet, 2002. "Being a citizen online: New opportunities and dead ends," International Journal of Press/Politics, volume 7, number 3, pp. 55-75. doi: http://dx.doi.org/10.1177/1081180X0200700304, accessed 20 February 2015

Kay L. Schlozman, Sidney Verba, and Henry E. Brady, 2010. "Weapon of the strong? Participatory inequality and the Internet," Perspectives on Politics, volume 8, number 2, pp. 487-509. doi: http://dx.doi.org/10.1017/S1537592710001210, accessed 20 February 2015

Joseph A. Schumpeter, 1952. Capitalism, socialism, and democracy. Fourth edition. London: Allen \& Unwin.

Dhavan V. Shah, Jack M. McLeod, and So-Hyang Yoon, 2001. "Communication, context, and community: An exploration of print, broadcast, and Internet influences," Communication Research, volume 28 , number 4, pp. 464-506. doi: http://dx.doi.org/10.1177/009365001028004005, accessed 20 February 2015.

Tanja Storsul, 2011. "Deliberation or self-presentation? Young people, politics and social media," paper presented at NordMedia 2011 (Akureiry, Iceland), at http://enqlish.unak.is/static/files/Storsul Tanja.pdf, accessed 26 May 2014

Gary Tang and Francis L.F. Lee, 2013. "Facebook use and political participation: The impact of exposure to shared political information, connections with public political actors, and network structural heterogeneity," Social Science Computer Review, volume 31, number 6, pp. 763-773. doi: http://dx.doi.org/10.1177/0894439313490625, accessed 20 February 2015.

John C. Tedesco, 2004. "Changing the channel: Use of the Internet for communicating about politics," In: Linda L. Kaid (editor). Handbook of political communication research. Mahwah, N.J.: Lawrence Erlbaum Associates, pp. 507-532.

Caroline J. Tolbert and Ramona S. McNeal, 2003. "Unravelling the effects of the Internet on political participation?" Political Research Quarterly, volume 56, number 2, pp. 175-185. doi: http://dx.doi.org/10.1177/106591290305600206, accessed 20 February 2015.

Terri L. Towner, 2013. "All political participation is socially networked? New media and the 2012 election," Social Science Computer Review, volume 31, number 5, pp. 527-541. doi: http://dx.doi.org/10.1177/0894439313489656, accessed 20 February 2015.

Zeynep Tufekci and Christopher Wilson, 2012. "Social media and the decision to participate in political protest: Observations from Tahrir Square," Journal of Communication, volume 62, number 2, pp. 363-379.

doi: http://dx.doi.org/10.1111/i.1460-2466.2012.01629.x, accessed 20 February 2015.

Sherry Turkle, 1996. "Virtuality and its discontents: Searching for community in cyberspace," American Prospect, volume 24, number 7, pp. 50-57. 
Cristian Vaccari, 2012. "Online participation in Italy: Contextual influences and political opportunities," In: Eva Anduiza, Michael J. Jensen, and Laia Jorba (editors). Digital media and political engagement worldwide: A comparative study. Cambridge: Cambridge University Press, pp. 138-159.

Sebastián Valenzuela, Namsu Park, and Kerk F. Kee, 2009. "Is there social capital in social network site? Facebook use and college students' life satisfaction, trust, and participation," Journal of Computer-Mediated Communication, volume 14, number 4, pp. 875-901. doi: http://dx.doi.org/10.1111/i.1083-6101.2009.01474.x, accessed 20 February 2015.

José van Dijck, 2013. The culture of connectivity: A critical history of social media. Oxford: Oxford University Press.

Sidney Verba, Kay L. Schlozman and Henry E. Brady, 1995. Voice and equality: Civic voluntarism in American politics. Cambridge, Mass.: Harvard University Press.

Lucia Vesnic-Alujevic, 2012. "Political participation and Web 2.0 in Europe: A case study of Facebook," Public Relations Review, volume 38, number 3, pp. 466-470.

doi: http://dx.doi.org/10.1016/i.pubrev.2012.01.010, accessed 20 February 2015.

Jessica Vitak, Paul Zube, Andrew Smock, Caleb T. Carr, Nicole Ellison, and Cliff Lampe, 2011. "It's complicated: Facebook users' political participation in the 2008 election," Cyberpsychology, Behavior, and Social Networking, volume 14, number 3, pp. 107-114. doi: http://dx.doi.org/10.1089/cyber.2009.0226, accessed 20 February 2015.

Song-In Wang, 2007. "Political use of the Internet, political attitudes and political participation," Asian Journal of Communication, volume 17, number 4, pp. 381-395. doi: http://dx.doi.org/10.1080/01292980701636993, accessed 20 February 2015.

Stephen Ward, Rachel Gibson, and Wainer Lusoli, 2003. "Online participation and mobilisation in Britain: Hype, hope and reality," Parliamentary Affairs, volume 56, number 4, pp. 652-668. doi: http://dx.doi.org/10.1093/pa/qsq108, accessed 20 February 2015.

Anne Marie Warren, Ainin Sulaiman, and Noor Ismawati Jaafar, 2014. "Facebook: The enabler of online civic engagement for activists," Computers in Human Behavior, volume 32, number 1, pp. 284-289.

doi: http://dx.doi.org/10.1016/i.chb.2013.12.017, accessed 20 February 2015.

Susan Waters and James Ackerman, 2011. "Exploring privacy management on Facebook: Motivations and perceived consequences of voluntary disclosure," Journal of Computer-Mediated Communication, volume 17, number 1, pp. 101-115. doi: http://dx.doi.org/10.1111/i.1083-6101.2011.01559.x, accessed 20 February 2015.

Lori M. Weber, Alysha Loumakis, and James Bergman, 2003. "Who participates and why? An analysis of citizens on the Internet and the mass public," Social Science Computer Review, volume 21 , number 1 , pp. 26-42.

doi: http://dx.doi.org/10.1177/0894439302238969, accessed 20 February 2015.

Christine B. Williams and Girish J. Gulati, 2007. "Social networks in political campaigns: Facebook and the 2006 midterm elections," paper presented at the American Political Science Association annual meeting (Chicago).

Michael Xenos, Ariadne Vromen, and Brian D. Loader, 2014. "The great equalizer? Patterns of social media use and youth political engagement in three advanced democracies," Information, Communication \& Society, volume 17, number 2, pp. 151-167. doi: http://dx.doi.org/10.1080/1369118X.2013.871318, accessed 20 February 2015.

Weiwu Zhang and Stella C. Chia, 2006. "The effects of mass media use and social capital on civic and political participation," Communication Studies, volume 57, number 3, pp. 277-297. doi: http://dx.doi.org/10.1080/10510970600666974, accessed 20 February 2015.

\section{Editorial history}

Received 25 July 2014; revised 11 February 2015; accepted 17 February 2015.

\section{c) (7) (2)}

"The Internet, social networking Web sites and political participation research: Assumptions and contradictory evidence" by Isidoropaolo Casteltrione is licensed under a Creative Commons Attribution-NonCommercial-ShareAlike 4.0 International License.

The Internet, social networking Web sites and political participation research: Assumptions and contradictory evidence 
by Isidoropaolo Casteltrione.

First Monday, Volume 20, Number 3 - 2 March 2015

http://firstmonday.org/ojs/index.php/fm/rt/printerFriendly/5462/4403

doi: http://dx.doi.org/10.5210/fm.v20i3.5462 